\title{
Effect of Semiarid Environment on Some Nutritional and Antinutritional Attributes of Calendula (Calendula officinalis)
}

\author{
Muhammad Iqbal, Iqbal Hussain, Asma Habib, \\ Muhammad Arslan Ashraf, and Rizwan Rasheed \\ Department of Botany, Government College University, Faisalabad 38000, Pakistan \\ Correspondence should be addressed to Muhammad Arslan Ashraf; arsilpk@gmail.com
}

Received 8 December 2014; Accepted 4 March 2015

Academic Editor: Iciar Astiasaran

Copyright @ 2015 Muhammad Iqbal et al. This is an open access article distributed under the Creative Commons Attribution License, which permits unrestricted use, distribution, and reproduction in any medium, provided the original work is properly cited.

\begin{abstract}
Stressful environments have been shown to affect the metabolism in some plants. In the present study, we assessed whether semiarid environment (saline and saline alkaline soil) could affect the nutritional (total proteins, phenolics and riboflavin contents, and catalase activity) and antinutritional (hydrogen peroxide and malondialdehyde contents) properties differently in different plant parts (leaves, flowers, and roots) of calendula. Although salinity decreased plant biomass, it did not affect total protein and phenolics contents in the calendula. All plant parts were rich in riboflavin contents. However, plants grown under saline-alkali soil had relatively more riboflavin contents in the flowers. Salinity increased hydrogen peroxide $\left(\mathrm{H}_{2} \mathrm{O}_{2}\right)$ concentration in the flowers and roots, whereas saline-alkali soil did not affect it. Plants exposed to both saline and saline-alkali soil had greater catalase activity in the flowers and leaves. Plants exposed to salinity had higher malondialdehyde (MDA) contents in the flowers compared with nonsaline and saline-alkali conditions. Nonetheless, the possibility of safely using different parts of calendula as nutraceutical was in the order flower $>$ root $>$ leaf. Overall, the results suggested that plant can be grown in mild saline-alkali $(\mathrm{EC} \leq 7 ; \mathrm{pH}=8.5)$ soils without affecting its nutraceutical properties.
\end{abstract}

\section{Introduction}

Calendula officinalis L. commonly known as marigold is an annual plant with yellow to orange flowers and is grown for medicinal [1-3] and ornamental uses [4-6]. All plant parts can be used either dried or fresh. The buds, leaves, and blossoms are used to formulate herbals and homeopathic medicines. Fresh flowers of $C$. officinalis and dried petals are used in salad and in tea, respectively. The flowers are also used in food industry to flavor cakes, cookies, and puddings as well as coloring of several culinary products $[7,8]$.

Plant based dietary supplements and natural botanicals are better sources of antioxidants and anti-inflammatory compounds [9]. Approximately $80 \%$ of the world population depend exclusively on plants for their health and healing. Pharmacological studies have shown that calendula exhibited a broad range of biological effects such as antimicrobial, anti-inflammatory [10, 11], antioxidant [12], wound healing [13], antiviral, and antitumoral [14]. It primarily contains two classes of pigments, the flavonoids and carotenoids. Plant based phenolics constituents retard oxidative degradation of lipids and thereby improve quality and nutritional value of food $[15,16]$. Flavonoids have antioxidant activities which play an important role in the food preservation and human health [17]. Calendula has a high number of carotenoids that are important antioxidants and are precursors of Vitamin A and retinoids [18].

Various environmental factors can affect growth, essential oil production, and other secondary products in plants [19, 20]. Although the natural products are gaining a revitalized attention in medical community and their therapeutic uses are gradually increasing, there is a lack of information about the effects of environmental conditions on the nutritional (functional food) and antinutritional (nonfood) properties of different medicinal plants. Different stresses have been shown to produce reactive oxygen species that result in the accumulation of toxic substances [21-24]. The most mutagenic lipid oxidation product is MDA [25]. It modifies 


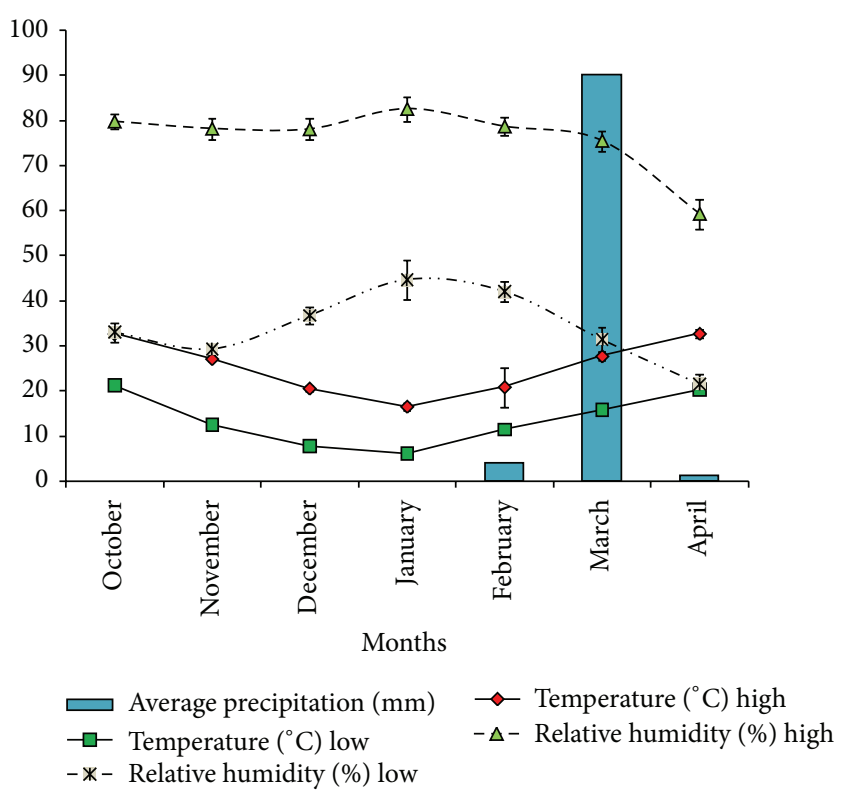

FIGURE 1: Meteorological data showing variations in temperature, relative humidity, and precipitation levels during the growing season of calendula. Sampling was done in the last week of February.

both proteins and DNA, and its reaction with proteins is associated with the development of pathological conditions such as atherosclerosis, diabetes, preeclampsia, Parkinson disease, and colon cancer [26]. A better strategy, therefore, is to look for the variation of natural substances like oxidants and antioxidants in the medicinal plants when grown under diverse environments. Accordingly, the primary objective of the study was to assess up to what extent semiarid environment could affect the nutritional and antinutritional properties of calendula.

\section{Materials and Methods}

2.1. Plant Materials and Growing Conditions. The experiment was conducted in the field under semiarid environmental conditions at University of Agriculture Faisalabad (UAF), Ayub Agricultural Research Institute, Faisalabad (AARI), and Government College University, Faisalabad (GCUF). The healthy calendula seeds were sown at the three sites and the germination percentage was over $75 \%$. The meteorological data during the growing season is shown in Figure 1. The $\mathrm{pH}$ and electrical conductivity $\left(\mathrm{EC}_{\mathrm{e}}\right.$ ) of the soil (from where the plants were uprooted) was tested before and after conduction of the experiment, and the average soil properties are shown in Figure 2. The plants were irrigated with tap water as and when required. All other agronomic practices were kept as normal and uniform at the three growing sites. At flowering stage (about 50 days after planting), the whole plants of calendula were uprooted, washed with distilled water so as to remove all unwanted material, and blotted and fresh weights were recorded. After drying at $65^{\circ} \mathrm{C}$ for $72 \mathrm{~h}$, shoot dry weights were recorded. The fresh, washed, and blotted plants were separated in to leaves, flowers, and roots for different

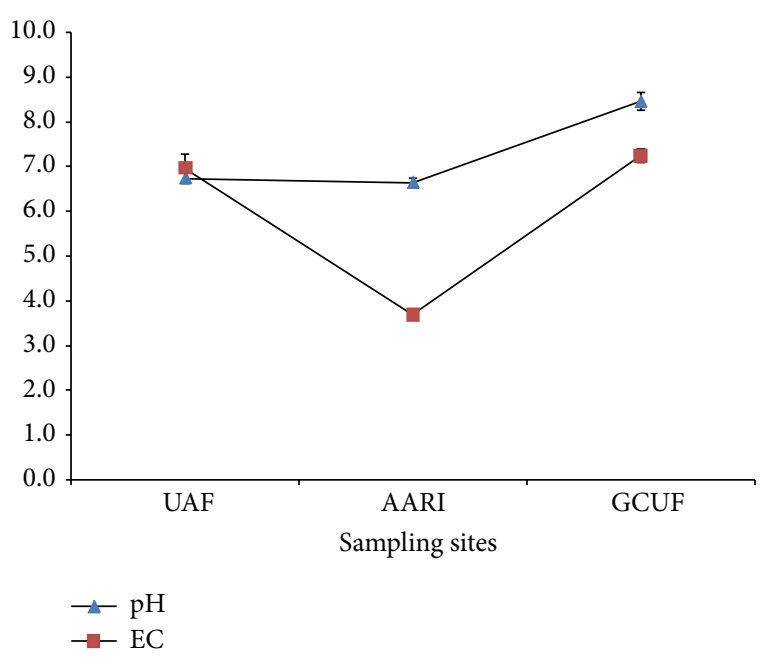

FIGURE 2: Chemical properties of soil collected from root zone of plants growing in semiarid zone. UAF: University of Agriculture, Faisalabad; AARI: Ayub Agricultural Research Institute, Faisalabad; GCUF: Government College University, Faisalabad; EC: electrical conductivity $\left(\mathrm{dS} \mathrm{m} \mathrm{m}^{-1}\right)$.

analyses. However, for total phenolics determination, plant parts dried at $40^{\circ} \mathrm{C}$ for 10 days were used.

2.2. Total Soluble Proteins. The concentration of total soluble protein was determined by using the method as described earlier [27]. Briefly, plant sample $(0.5 \mathrm{~g})$ was taken and grounded in $10 \mathrm{~mL}$ phosphate buffer ( $\mathrm{pH} 7.8)$. After centrifugation at $16,000 \mathrm{~g}$ for $15 \mathrm{~min}$ at $4^{\circ} \mathrm{C}$, the supernatant was treated with $2 \mathrm{~mL}$ Bradford reagent and incubated for $15 \mathrm{~min}$. The absorbance was measured at $595 \mathrm{~nm}$. Total soluble proteins were computed using standard graph using bovine serum albumin (BSA) as standard.

2.3. Riboflavin Concentration. The concentration of riboflavin was determined by using the method of Okwu and Josiah [28]. Plant sample $(1 \mathrm{~g})$ was extracted with $20 \mathrm{~mL}$ of $50 \%$ ethanol for $1 \mathrm{~h}$. To the supernatant $(5 \mathrm{~mL}), 5 \mathrm{~mL}$ of $5 \%$ potassium permanganate and $4.5 \mathrm{~mL}$ of $30 \% \mathrm{H}_{2} \mathrm{O}_{2}$ were added and allowed to stand over a hot water bath for $30 \mathrm{~min}$. Then, $1 \mathrm{~mL}$ of $40 \%$ sodium sulphate was added and the volume was made up to $25 \mathrm{~mL}$. The absorbance was measured at $510 \mathrm{~nm}$ with a spectrophotometer.

2.4. Total Phenolics. Total phenolics were determined by using Folin-Ciocalteu method with some modifications [29]. Briefly, the extracts were mixed with $5 \mathrm{~mL}$ of diluted $(1: 10$ $\mathrm{v} / \mathrm{v})$ Folin-Ciocalteu reagent and $4 \mathrm{~mL}$ of sodium carbonate solution $(75 \mathrm{~g} / \mathrm{L})$. The tubes were vortexed for $15 \mathrm{~s}$ and then incubated at $40^{\circ} \mathrm{C}$ for $30 \mathrm{~min}$. The absorbance was measured at $765 \mathrm{~nm}$ using the UV-VIS spectrophotometer (Hitachi U-2910). Total phenolic contents were expressed as $\mathrm{mg} \mathrm{g}^{-1}$ tannic acid equivalent (TAE).

2.5. Catalase (CAT) Activity. The CAT activity was determined as previously described [30]. Briefly, the reaction 
solution $(3 \mathrm{~mL})$ for CAT was comprised of $50 \mathrm{mM}$ phosphate buffer ( $\mathrm{pH}$ 7.0), $15 \mathrm{mM} \mathrm{H}_{2} \mathrm{O}_{2}$, and $50 \mu \mathrm{L}$ enzyme extract. Reaction was initiated by the addition of $\mathrm{H}_{2} \mathrm{O}_{2}$ to the reaction solution. The CAT activity was determined by following the decomposition of $\mathrm{H}_{2} \mathrm{O}_{2}$ and measuring the absorbance decrease at $240 \mathrm{~nm}$ for $1 \mathrm{~min}$. The CAT activity was expressed as $\mu \mathrm{kat} \mathrm{mg}^{-1}$ protein $\mathrm{min}^{-1}$.

2.6. MDA Contents. The MDA was determined as described earlier [31]. Briefly, in $2 \mathrm{~mL}$ of supernatant, $2 \mathrm{~mL}$ of $0.6 \%$ thiobarbituric acid was added and incubated at $100^{\circ} \mathrm{C}$ for $20 \mathrm{~min}$ in water bath. After heating, the samples were immediately cooled in ice-bath and centrifuged at 20,000 g for $10 \mathrm{~min}$. The absorbance of the supernatant was recorded at $450 \mathrm{~nm}$, $532 \mathrm{~nm}$, and $600 \mathrm{~nm}$ on UV-VIS spectrophotometer (Hitachi U-2910). The MDA contents ( $\mathrm{mmol} \mathrm{g}^{-1} \mathrm{FW}$ ) were calculated according to the given formula:

$$
[\mathrm{MDA}]=6.45 \times\left(\mathrm{A}_{532}-\mathrm{A}_{600}\right)-0.56 \times \mathrm{A}_{450} .
$$

2.7. $\mathrm{H}_{2} \mathrm{O}_{2}$ Concentration. The $\mathrm{H}_{2} \mathrm{O}_{2}$ concentration was determined following Velikova et al. [32]. Briefly, fresh leaves $(0.1 \mathrm{~g})$ were homogenized in $5 \mathrm{~mL}$ of $0.1 \%$ trichloroacetic acid (TCA). After centrifugation at $12,000 \mathrm{rpm}$ for $15 \mathrm{~min}$, the supernatant $(0.5 \mathrm{~mL})$ was then mixed with $0.5 \mathrm{~mL}$ of phosphate buffer $(\mathrm{pH} 7)$ and $1 \mathrm{~mL}$ of $1 \mathrm{M} \mathrm{KI}$. After incubation, the absorbance was taken at $390 \mathrm{~nm}$. The content of $\mathrm{H}_{2} \mathrm{O}_{2}$ was determined using a calibration curve constructed using a series $(1-50 \mu \mathrm{M})$ of analytic grade $\mathrm{H}_{2} \mathrm{O}_{2}$.

2.8. Statistical Analysis. The data collected was subjected to analysis of variance technique (ANOVA) by using a computer software CoStat version 6.2, CoHort Software, 2003, Monterey, CA, USA. When the difference among means was significant $(P \leq 0.05)$, the mean values were compared using the least significant difference (LSD).

\section{Results}

3.1. Plant Biomass and Nutritional Properties. Calendula exhibited more growth in terms of fresh and dry masses under nonsaline conditions ( $\mathrm{EC} \leq 4 \mathrm{dS} \mathrm{m}^{-1}$ ) (Figure 3). However, the minimum fresh and dry masses of calendula were observed under saline and saline-alkali environment.

Arid environment nonsignificantly affected total protein contents in all calendula parts (leaf, flower, and root) (Figure 4(a)). However, the environmental conditions significantly affected riboflavin (Vitamin B2) concentration in all tissues of calendula (Figure 4(b)). Interestingly, plants growing in saline-alkali environment had maximum riboflavin concentration in the flowers and the minimum riboflavin concentration in the roots. Irrespective of the growing conditions, all plant parts (flower, leaf, and root) were rich in riboflavin contents.

In the present study, changes in environmental conditions had nonsignificant effect on the total phenolics contents in different plant parts (Figure 5(a)). Nonetheless, growing conditions significantly affected CAT activity in all calendula parts (leaves, flowers, and roots) (Figure 5(b)). Plants

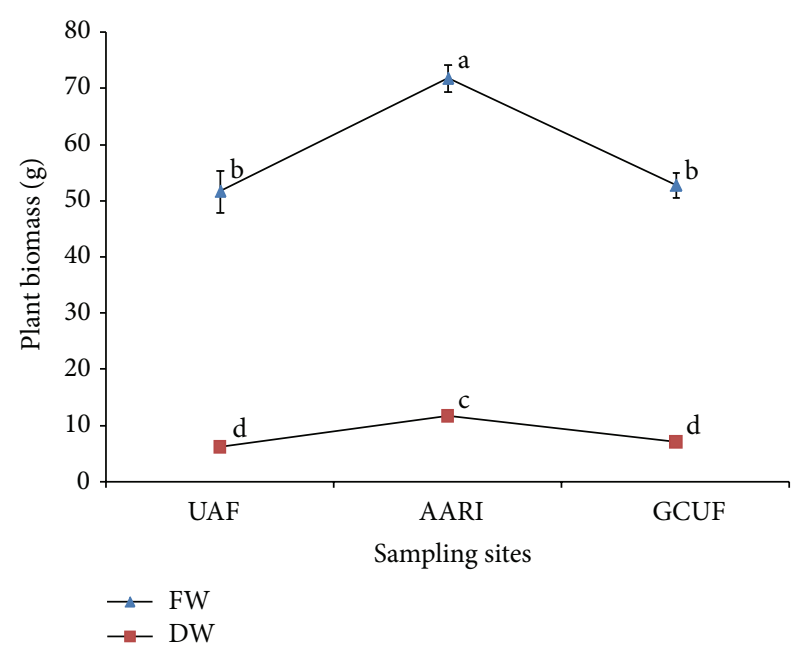

FIGURE 3: Shoot biomass (fresh and dry weights) of calendula plants collected from semiarid zone. Values $(n=9 \pm$ SE) with different superscripts $(\mathrm{a}-\mathrm{d})$ are significantly different at $P<0.05$.

collected from saline and saline-alkali environment had more CAT activity in the flowers as compared with plants grown in the nonsaline environment. Overall, growing conditions did not affect CAT activity in the roots of calendula. The minimum CAT activity was observed in the leaves of plants grown in nonsaline environment.

3.2. Antinutritional Properties. Changes in environmental conditions significantly affected $\mathrm{H}_{2} \mathrm{O}_{2}$ concentration in all plant parts (Figure 6(a)). Nonetheless, flowers had more $\mathrm{H}_{2} \mathrm{O}_{2}$ concentration followed by leaves and roots under different growing conditions. Salinity caused greater $\mathrm{H}_{2} \mathrm{O}_{2}$ accumulation in the calendula roots when compared with nonsaline and saline-alkali regimes.

Arid environment significantly affected MDA concentration in all parts of calendula (Figure 6(b)). Salinity increased MDA concentration in the flowers while nonsaline and saline-alkali regime increased MDA concentration in the leaves. In contrast, saline-alkali environment increased MDA concentration in the roots when compared with nonsaline and saline environments.

\section{Discussion}

Changes in environmental conditions (abiotic stresses) have been shown to affect the physiochemical attributes in different plants [33-35]. In the present study, soil salinity and alkalinity decreased plant biomass. However, different environments did not affect total proteins contents in calendula. Earlier studies have shown variable effects of different environments on total proteins contents in different plants. For instance, salinity did not affect total soluble protein content in narrow-leafed lupine [36] and wheat [37]. In contrast, salinity significantly decreased protein contents in some plants [38, 39]. Khedr et al. [40] found an increase in protein content at low and decline at high $\mathrm{NaCl}$ levels in both shoot and root of Pancratium maritimum. Our results 


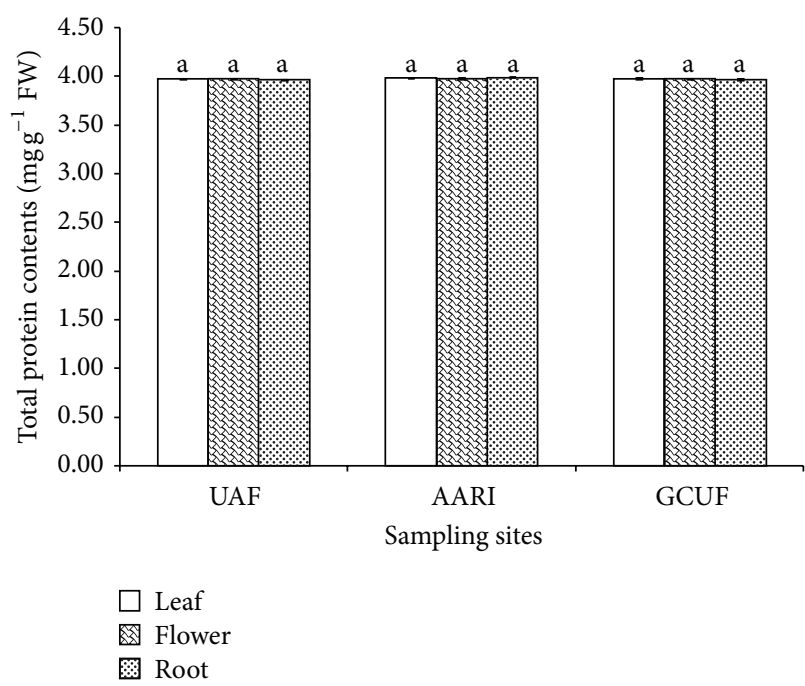

(a)

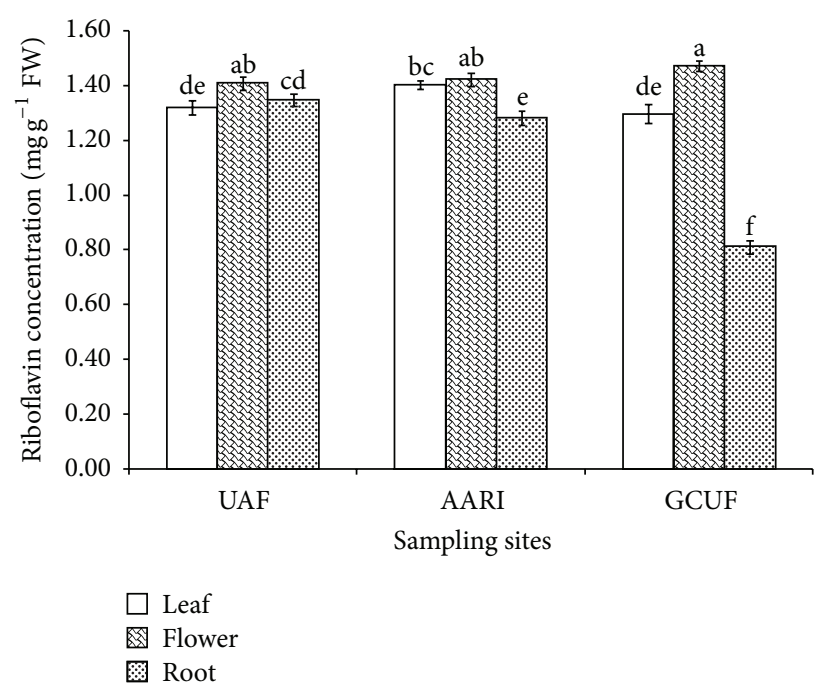

(b)

FIGURE 4: Total protein concentration (a) and riboflavin concentration (b) in different tissues of calendula plants collected from semiarid zone. Values $(n=9 \pm \mathrm{SE})$ with different superscripts $(\mathrm{a}-\mathrm{f})$ are significantly different at $P<0.05$.

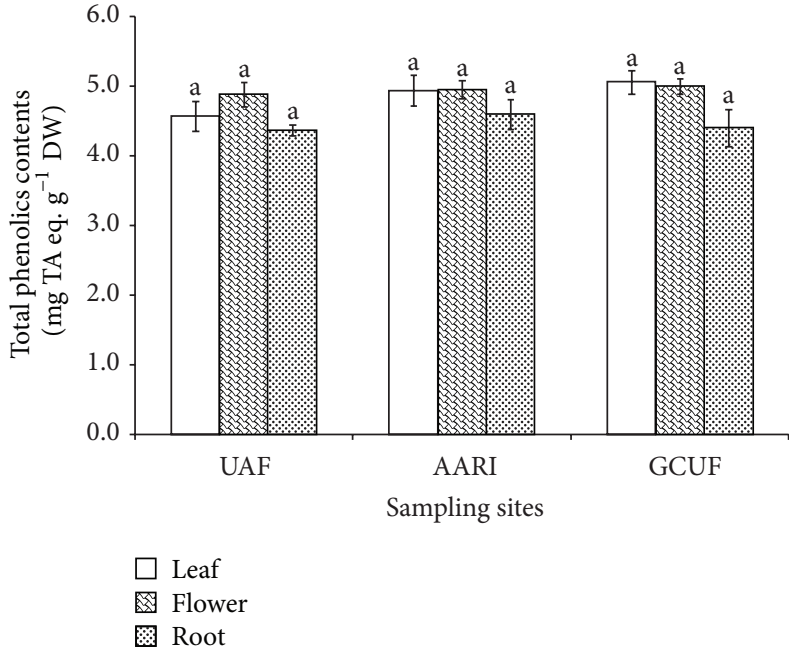

(a)

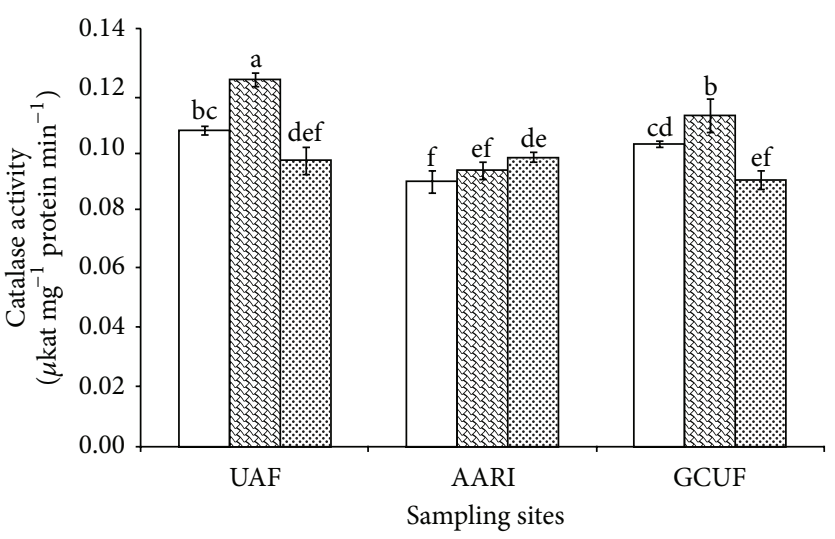

$\square$ Leaf
Flower
Root

(b)

Figure 5: Total phenolics (a) and catalase activity (b) in different tissues of calendula plants collected from semi-arid zone. Values $(n=9 \pm$ SE) with different superscripts $(\mathrm{a}-\mathrm{f})$ are significantly different at $P<0.05$. GA eq.: gallic acid equivalent.

suggested that calendula could be grown under mild saline or saline-alkali environments without affecting its nutritional value in terms of soluble protein contents.

Riboflavin is used for human nutrition and therapy and also as an animal feed additive. Riboflavin produced by plants acts as a coenzyme in many physiological reactions in plants and animals $[41,42]$. In this work, saline-alkali environment increased riboflavin concentration in the flowers whereas it was decreased in the roots. This showed that different calendula tissues faced stress differently. Nonetheless, calendula accumulated higher riboflavin concentration in the flowers under different environments. Riboflavin, being an antioxidant [43], affected $\mathrm{H}_{2} \mathrm{O}_{2}$ accumulation in Arabidopsis thaliana [44]. Jaleel et al. [45] stated that higher riboflavin contents could decrease the membrane degradation under stressful environments possibly by preventing lipid peroxidation [46]. Accordingly, our results suggested that higher concentration of riboflavin in the flowers could increase membrane stability and thus increase longevity of flowers. Furthermore, flowers being rich in riboflavin contents could be used as functional food.

Phenolics are the most abundant secondary metabolites of plant origin which form an important part of both human and animal diets. Phenolics are more potent antioxidants than Vitamins $\mathrm{C}$ and $\mathrm{E}$ and carotenoids because phenolics could act as hydrogen donators, reducing agents and 

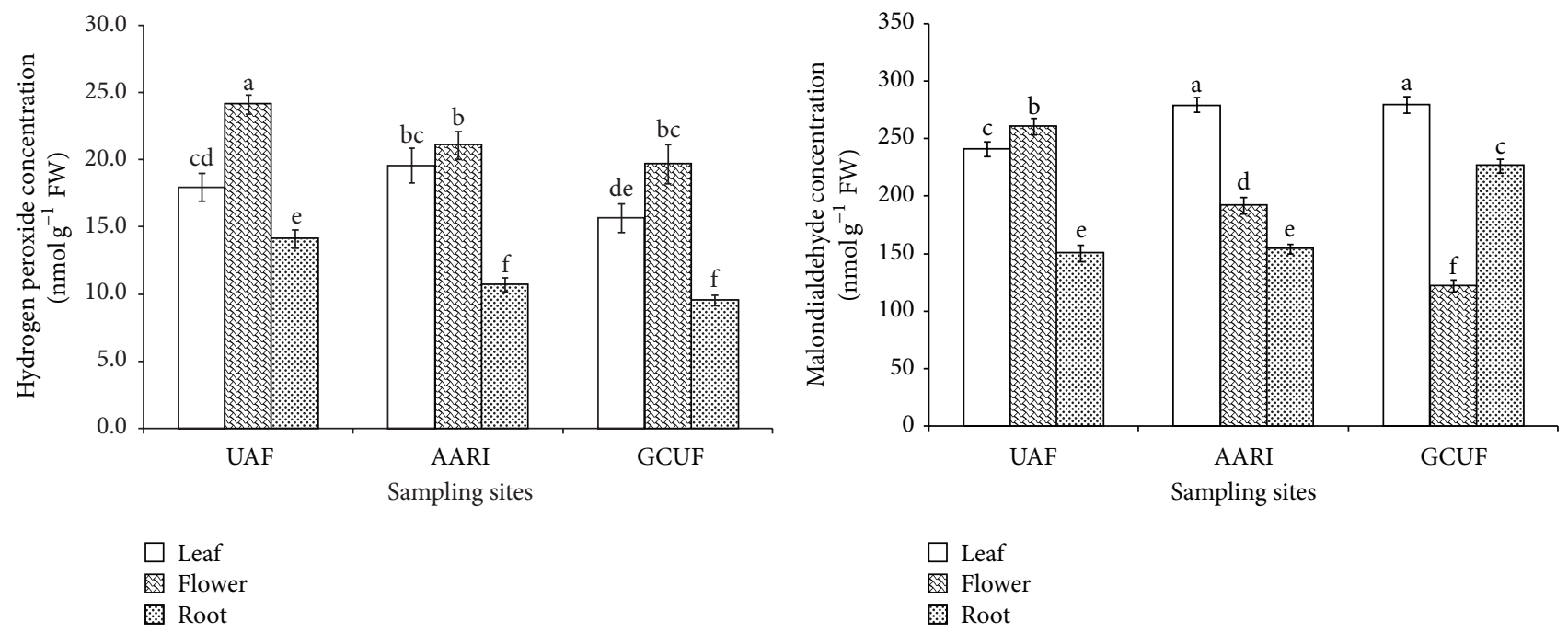

(a)

(b)

Figure 6: Hydrogen peroxide $\left(\mathrm{H}_{2} \mathrm{O}_{2}\right)$ (a) and malondialdehyde (MDA) concentration (b) in different tissues of calendula plants collected from semiarid zone. Values $(n=9 \pm \mathrm{SE})$ with different superscripts $(\mathrm{a}-\mathrm{f})$ are significantly different at $P<0.05$.

quenchers of singlet oxygen $[47,48]$, and thus it prevents the stress-induced oxidative stress [49]. Both saline and saline-alkali environments did not affect total phenolics in different calendula parts. The results suggested that calendula plants might have faced less stress under different regimes. Furthermore, plants might have used another antioxidative pathway/kind of antioxidants to cope with the stressful environment. Nonetheless, phenolics played an important role in the abiotic stress tolerance in some plants [50], where the synthesis of soluble phenolics directly correlated with the stress tolerance [51]. All tissues of calendula accumulated phenolics irrespective of the growing environment. The favourable activity of the calendula in a number of health related matters has also been associated with the accumulation of total phenolics [9].

Catalases are used to decrease oxidants like $\mathrm{H}_{2} \mathrm{O}_{2}$ [52]. In the present study, more CAT activity was observed in the flowers of calendula grown under both saline and salinealkali conditions. A contrasting response of CAT activity to different abiotic stresses has been shown in the literature. For instance, salinity stress enhanced CAT activity in rice plants $[53,54]$, whereas it was downregulated in some other plants [55]. This could be either due to salt stress-induced degradation of CAT by endogenous proteases or inhibition of CAT activity by the accumulation of salicylic acid [56]. Earlier studies have shown that calendula extract efficiently scavenged different radicals in vitro [57]. The results suggested that extract of calendula flowers particularly collected from stressful environments could be effectively used to scavenge different radicals.

Plants grown under salt stress are prone to oxidative damage induced by the elevated levels of reactive oxygen species (ROS) such as hydrogen peroxide [58-60]. In the present investigations, both flowers and roots of calendula accumulated higher levels of $\mathrm{H}_{2} \mathrm{O}_{2}$ under saline regimes compared with nonsaline and saline-alkali conditions. Relatively, leaves of plants growing in nonsaline environment had slightly more $\mathrm{H}_{2} \mathrm{O}_{2}$ contents compared with those growing in saline and saline-alkali environments. This could be due to either less synthesis or activity of different antioxidative enzymes that altered $\mathrm{H}_{2} \mathrm{O}_{2}$ concentration in leaves under nonsaline conditions. Higher cellular $\mathrm{H}_{2} \mathrm{O}_{2}$ levels have been shown to adversely affect anthocyanins and ascorbic acid contents in different plants [61, 62]. Hydrogen peroxide mediated cell damage was associated with the initiation and progression of many diseases [63]. In vivo, although $\mathrm{H}_{2} \mathrm{O}_{2}$ is short-lived [64], it is highly toxic and induces cell death in vitro [65]. The present results suggested that roots of calendula plants should be preferred over other parts having low $\mathrm{H}_{2} \mathrm{O}_{2}$ concentrations when collected from saline environments.

Lipid peroxidation is a major problem in the food industry. It leads to quality deterioration, rancidity, and accumulation of potentially toxic compounds in foods [66]. One of the major and most toxic by-products of lipid peroxidation is MDA [24, 67]. Several deleterious effects of MDA have been reported such as induction of intracellular oxidative stress [24] and formation of highly mutagenic DNA adducts in human cells [68]. When ingested, MDA increases frequencies of tumour and atherosclerosis [66] and modifies both proteins and DNA [67]. In the present study, salinity increased MDA contents in the flowers while nonsaline and saline-alkali environment increased MDA contents in the leaves. Salinity mediated increased production of MDA has been shown in many plants $[37,65,68]$. Interestingly, plants grown under saline-alkali conditions had less MDA contents in the flowers and more in the roots. This could be due to the reason that flowers accumulated antioxidants such as riboflavin and phenolics and had higher CAT activity that scavenged $\mathrm{H}_{2} \mathrm{O}_{2}$ and possibly prevented lipid peroxidation.

In conclusion, flowers collected from nonsaline and saline-alkali environments (ECe $\leq 7 \mathrm{dS} / \mathrm{m}$ ) and roots from saline environments (ECe $>7 \mathrm{dS} / \mathrm{m}$ ) should be preferred 
over other plant parts being more safe having relatively low antinutritive $\left(\mathrm{H}_{2} \mathrm{O}_{2}\right.$ and MDA) contents. Overall, based on higher nutritive and low antinutritive contents, the possibility of using different parts of calendula as food additive/nutraceutical was in the order flower $>$ root $>$ leaf.

\section{Conflict of Interests}

The authors declare that there is no conflict of interests regarding the publication of this paper.

\section{Authors' Contribution}

Muhammad Iqbal and Asma Habib planned the research work and Muhammad Iqbal supervised the whole research work. Asma Habib performed the experiment and done sampling and analyses. Iqbal Hussain, Muhammad Arslan Ashraf, and Rizwan Rasheed contributed in data analysis. Muhammad Iqbal and Muhammad Arslan Ashraf wrote the paper. All authors read and approved the final paper.

\section{References}

[1] S. Mohammad and H. H. Kashani, "Pot marigold (Calendula officinalis) medicinal usage and cultivation," Scientific Research and Essays, vol. 7, no. 14, pp. 1468-1472, 2012.

[2] K. C. Preethi and R. Kuttan, "Wound healing activity of flower extract of Calendula officinalis," Journal of Basic and Clinical Physiology and Pharmacology, vol. 20, no. 1, pp. 73-79, 2009.

[3] P. K. Chandran and R. Kuttan, "Effect of Calendula officinalis flower extract on acute phase proteins, antioxidant defense mechanism and granuloma formation during thermal burns," Journal of Clinical Biochemistry and Nutrition, vol. 43, no. 2, pp. 58-64, 2008.

[4] C. Ao, "Comparative anatomy of bisexual and female florets, embryology in Calendula officinalis (Asteraceae), a naturalized horticultural plant," Scientia Horticulturae, vol. 114, no. 3, pp. 214-219, 2007.

[5] M. Alexenizer and A. Dorn, "Screening of medicinal and ornamental plants for insecticidal and growth regulating activity," Journal of Pest Science, vol. 80, no. 4, pp. 205-215, 2007.

[6] E. M. R. Clark, J. M. Dole, A. S. Carlson et al., "Vase life of new cut flower cultivars," HortTechnology, vol. 20, no. 6, pp. 10161025, 2010.

[7] G. S. Ćetković, S. M. Djilas, J. M. Čanadanović-Brunet, and V. T. Tumbas, "Antioxidant properties of marigold extracts," Food Research International, vol. 37, no. 7, pp. 643-650, 2004.

[8] J. A. Duke, "The garden pharmacy: pot marigold: an herbal florin for health," Alternative and Complementary Therapies, vol. 14, no. 3, pp. 109-115, 2008.

[9] M. Y. Khalil, A. A. Moustafa, and N. Y. Naguib, "Growth, phenolic compounds and antioxidant activity of some medicinal plants grown under organic farming condition," World Journal of Agricultural Sciences, vol. 3, no. 4, pp. 451-457, 2007.

[10] B. Amoian, A. A. Moghadamnia, M. Mazandarani, M. M. Amoian, and S. Mehrmanesh, "The effect of calendula extract toothpaste on the plaque index and bleeding in gingivitis," Research Journal of Medicinal Plant, vol. 4, no. 3, pp. 132-140, 2010.
[11] E. M. Sarrell, A. Mandelberg, and H. A. Cohen, "Efficacy of naturopathic extracts in the management of ear pain associated with acute otitis media," Archives of Pediatrics and Adolescent Medicine, vol. 155, no. 7, pp. 796-799, 2001.

[12] H. Masaki, "Role of antioxidants in the skin: anti-aging effects," Journal of Dermatological Science, vol. 58, no. 2, pp. 85-90, 2010.

[13] K. C. Preethi, G. Kuttan, and R. Kuttan, "Antioxidant potential of an extract of Calendula officinalis flowers in vitro and in vivo," Pharmaceutical Biology, vol. 44, no. 9, pp. 691-697, 2006.

[14] M. Ukiya, T. Akihisa, K. Yasukawa, H. Tokuda, T. Suzuki, and Y. Kimura, "Anti-inflammatory, anti-tumor-promoting, and cytotoxic activities of constituents of marigold (Calendula officinalis) flowers," Journal of Natural Products, vol. 69, no. 12, pp. 1692-1696, 2006.

[15] C. A. Rice-Evans, N. J. Miller, P. G. Bolwell, P. M. Bramley, and J. B. Pridham, "The relative antioxidant activities of plant-derived polyphenolic flavonoids," Free Radical Research, vol. 22, no. 4, pp. 375-383, 1995.

[16] L. G. Landry, C. C. S. Chapple, and R. L. Last, "Arabidopsis mutants lacking phenolic sunscreens exhibit enhanced ultraviolet-B injury and oxidative damage," Plant Physiology, vol. 109, no. 4, pp. 1159-1166, 1995.

[17] A. Meda, C. E. Lamien, M. Romito, J. Millogo, and O. G. Nacoulma, "Determination of the total phenolic, flavonoid and proline contents in Burkina Fasan honey, as well as their radical scavenging activity," Food Chemistry, vol. 91, no. 3, pp. 571-577, 2005.

[18] J. J. M. Castenmiller and C. E. West, "Bioavailability and bioconversion of carotenoids," Annual Review of Nutrition, vol. 18, pp. 19-38, 1998.

[19] S. Fatima, A. H. A. Farooqi, S. R. Ansari, and S. Sharma, "Effect of water stress on growth and essential oil metabolism in Cymbopogon martinii (Palmarosa) cultivars," Journal of Essential Oil Research, vol. 11, no. 4, pp. 491-496, 1999.

[20] S. Mahmood, A. Wahid, R. Rasheed, I. Hussain, and S. M. A. Basra, "Possible antioxidative role of endogenous vitamins biosynthesis in heat stressed maize (Zea mays)," International Journal of Agriculture and Biology, vol. 14, no. 5, pp. 705-712, 2012.

[21] L. Tesoriere, D. D’Arpa, D. Butera, A. M. Pintaudi, M. Allegra, and M. A. Livrea, "Exposure to malondialdehyde induces an early redox unbalance preceding membrane toxicity in human erythrocytes," Free Radical Research, vol. 36, no. 1, pp. 89-97, 2002.

[22] C. Wood, "Free Radicals in Biology and Medicine. Third Edition: Barry Halliwell and John M.C. Gutteridge, Oxford University Press. ISBN 1-29-850044-0/45-0. H/B £75.00, P/B $£ 34.95$," The International Journal of Biochemistry \& Cell Biology, vol. 31, no. 12, p. 1454, 1999.

[23] S. Riaz, M. Iqbal, I. Hussain et al., "Chronic cadmium induced oxidative stress not the DNA fragmentation modulates growth in spring wheat (Triticum aestivum)," International Journal of Agriculture and Biology, vol. 16, no. 4, pp. 789-794, 2014.

[24] R. Rasheed, M. A. Ashraf, S. Parveen, M. Iqbal, and I. Hussain, "Effect of Salt Stress on Different Growth and Biochemical Attributes in Two Canola (Brassica napus L.) Cultivars," Communications in Soil Science and Plant Analysis, vol. 45, no. 5, pp. 669-679, 2014.

[25] A. N. Onyango and N. Baba, "New hypotheses on the pathways of formation of malondialdehyde and isofurans," Free Radical Biology and Medicine, vol. 49, no. 10, pp. 1594-1600, 2010. 
[26] I. Dalle-Donne, R. Rossi, R. Colombo, D. Giustarini, and A. Milzani, "Biomarkers of oxidative damage in human disease," Clinical Chemistry, vol. 52, no. 4, pp. 601-623, 2006.

[27] M. M. Bradford, "A rapid and sensitive method for the quantitation of microgram quantities of protein utilizing the principle of protein dye binding," Analytical Biochemistry, vol. 72, no. 1-2, pp. 248-254, 1976.

[28] D. E. Okwu and C. Josiah, "Evaluation of the chemical composition of two Nigerian medicinal plants," African Journal of Biotechnology, vol. 5, no. 4, pp. 357-361, 2006.

[29] K. Wolfe, X. Wu, and R. H. Liu, "Antioxidant activity of apple peels," Journal of Agricultural and Food Chemistry, vol. 51, no. 3, pp. 609-614, 2003.

[30] I. Cakmak, D. Strbac, and H. Marschner, "Activities of hydrogen peroxide-scavenging enzymes in germinating wheat seeds," Journal of Experimental Botany, vol. 44, no. 1, pp. 127-132, 1993.

[31] R. S. Dhindsa, P. Plumb-Dhindsa, and T. A. Thorpe, "Leaf senescence: correlated with increased levels of membrane permeability and lipid peroxidation, and decreased levels of superoxide dismutase and catalase," Journal of Experimental Botany, vol. 32, no. 1, pp. 93-101, 1981.

[32] V. Velikova, I. Yordanov, and A. Edreva, "Oxidative stress and some antioxidant systems in acid rain-treated bean plants protective role of exogenous polyamines," Plant Science, vol. 151, no. 1, pp. 59-66, 2000.

[33] C. Abdul Jaleel, G. M. A. Lakshmanan, M. Gomathinayagam, and R. Panneerselvam, "Triadimefon induced salt stress tolerance in Withania somnifera and its relationship to antioxidant defense system," South African Journal of Botany, vol. 74, no. 1, pp. 126-132, 2008.

[34] M. Iqbal and M. Ashraf, "Changes in hormonal balance: a possible mechanism of pre-sowing chilling-induced salt tolerance in spring wheat," Journal of Agronomy and Crop Science, vol. 196, no. 6, pp. 440-454, 2010.

[35] Z. Zhang, H. Li, S. Qiao, X. Zhang, P. Liu, and X. Liu, "Effect of salinity on seed germination, seedling growth, and physiological characteristics of Perilla frutescens," Plant Biosystems, vol. 146, no. 2, pp. 245-251, 2012.

[36] Q. Yu and Z. Rengel, "Drought and salinity differentially influence activities of superoxide dismutases in narrow-leafed lupins," Plant Science, vol. 142, no. 1, pp. 1-11, 1999.

[37] S. Perveen, M. Shahbaz, and M. Ashraf, "Modulation in activities of antioxidant enzymes in salt stressed and non-stressed wheat (Triticum aestivum L.) plants raised from seed treated with triacontanol," Pakistan Journal of Botany, vol. 43, no. 5, pp. 2463-2468, 2011

[38] A. Parvaiz and S. Satyawati, "Salt stress and phyto-biochemical responses of plants-a review," Plant, Soil and Environment, vol. 54, no. 3, pp. 89-99, 2008.

[39] Z. B. Doganlar, K. Demir, H. Basak, and K. Gul, "Effects of salt stress on pigment and total soluble protein contents of three different tomato cultivars," African Journal of Agricultural Research, vol. 5, no. 15, pp. 2056-2065, 2010.

[40] A. H. A. Khedr, M. A. Abbas, A. A. Abdel Wahid, W. P. Quick, and G. M. Abogadallah, "Proline induces the expression of saltstress-responsive proteins and may improve the adaptation of Pancratium maritimum L. to salt-stress," Journal of Experimental Botany, vol. 54, no. 392, pp. 2553-2562, 2003.

[41] G. Gastaldi, U. Laforenza, D. Casirola, G. Ferrari, M. Tosco, and G. Rindi, "Energy depletion differently affects membrane transport and intracellular metabolism of riboflavin taken up by isolated rat enterocytes," Journal of Nutrition, vol. 129, no. 2, pp. 406-409, 1999.

[42] M. Ouyang, J. Ma, M. Zou et al., "The photosensitive phs1 mutant is impaired in the riboflavin biogenesis pathway," Journal of Plant Physiology, vol. 167, no. 17, pp. 1466-1476, 2010.

[43] D. D. Wang and D. D.-S. Tzeng, "Methionine-riboflavin mixtures with surfactants and metal ions reduce powdery mildew infection in strawberry plants," Journal of the American Society for Horticultural Science, vol. 123, no. 6, pp. 987-991, 1998.

[44] B. Deng, S. Deng, F. Sun, S. Zhang, and H. Dong, "Downregulation of free riboflavin content induces hydrogen peroxide and a pathogen defense in Arabidopsis," Plant Molecular Biology, vol. 77, no. 1, pp. 185-201, 2011.

[45] C. A. Jaleel, R. Gopi, G. M. A. Alagu Lakshmanan, and R. Panneerselvam, "Triadimefon induced changes in the antioxidant metabolism and ajmalicine production in Catharanthus roseus (L.) G. Don," Plant Science, vol. 171, no. 2, pp. 271-276, 2006.

[46] C. A. Rice-Evans, N. J. Miller, and G. Paganga, "Antioxidant properties of phenolic compounds," Trends in Plant Science, vol. 2, no. 4, pp. 152-159, 1997.

[47] J. Dai and R. J. Mumper, "Plant phenolics: extraction, analysis and their antioxidant and anticancer properties," Molecules, vol. 15, no. 10, pp. 7313-7352, 2010.

[48] M. Hejazi Mehrizi, H. Shariatmadari, A. H. Khoshgoftarmanesh, and F. Dehghani, "Copper effects on growth, lipid peroxidation, and total phenolic content of rosemary leaves under salinity stress," Journal of Agricultural Science and Technology, vol. 14, no. 1, pp. 205-212, 2012.

[49] F. Alén-Ruiz, M. S. García-Falcón, M. C. Pérez-Lamela, E. Martínez-Carballo, and J. Simal-Gándara, "Influence of major polyphenols on antioxidant activity in Mencía and Brancellao red wines," Food Chemistry, vol. 113, no. 1, pp. 53-60, 2009.

[50] I. Ślesak, M. Libik, B. Karpinska, S. Karpinski, and Z. Miszalski, "The role of hydrogen peroxide in regulation of plant metabolism and cellular signalling in response to environmental stresses," Acta Biochimica Polonica, vol. 54, no. 1, pp. 39-50, 2007.

[51] J. M. Almeida, F. Fidalgo, A. Confraria, A. Santos, H. Pires, and I. Santos, "Effect of hydrogen peroxide on catalase gene expression, isoform activities and levels in leaves of potato sprayed with homobrassinolide and ultrastructural changes in mesophyll cells," Functional Plant Biology, vol. 32, no. 8, pp. 707720, 2005.

[52] H. Vaidyanathan, P. Sivakumar, R. Chakrabarty, and G. Thomas, "Scavenging of reactive oxygen species in $\mathrm{NaCl}$-stressed rice (Oryza sativa L.)-differential response in salt-tolerant and sensitive varieties," Plant Science, vol. 165, no. 6, pp. 1411-1418, 2003.

[53] A. Basile, S. Sorbo, B. Conte et al., "Antioxidant activity in extracts from Leptodictyum riparium (Bryophyta), stressed by heavy metals, heat shock, and salinity," Plant Biosystems, vol. 145, no. 1, pp. 77-80, 2011.

[54] I.-S. Shim, Y. Momose, A. Yamamoto, D.-W. Kim, and K. Usui, "Inhibition of catalase activity by oxidative stress and its relationship to salicylic acid accumulation in plants," Plant Growth Regulation, vol. 39, no. 3, pp. 285-292, 2003.

[55] G. Matysik, M. Wójciak-Kosior, and R. Paduch, "The influence of Calendulae officinalis flos extracts on cell cultures, and the chromatographic analysis of extracts," Journal of Pharmaceutical and Biomedical Analysis, vol. 38, no. 2, pp. 285-292, 2005.

[56] R. K. Sairam and G. C. Srivastava, "Induction of oxidative stress and antioxidant activity by hydrogen peroxide treatment in 
tolerant and susceptible wheat genotypes," Biologia Plantarum, vol. 43, no. 3, pp. 381-386, 2000.

[57] H. Dallali, E. M. Maalej, N. G. Boughanmi, and R. Haouala, "Salicylic acid priming in Hedysarum carnosum and Hedysarum coronarium reinforces $\mathrm{NaCl}$ tolerance at germination and the seedling growth stage," Australian Journal of Crop Science, vol. 6, no. 3, pp. 407-414, 2012.

[58] P. Sharma, A. B. Jha, R. S. Dubey, and M. Pessarakli, "Reactive oxygen species, oxidative damage, and antioxidative defense mechanism in plants under stressful conditions," Journal of Botany, vol. 2012, Article ID 217037, 26 pages, 2012.

[59] G. Özkan, O. Sagdiç, N. G. Baydar, and H. Baydar, "Antioxidant and antibacterial activities of Rosa damascena flower extracts," Food Science and Technology International, vol. 10, no. 4, pp. 277-281, 2004.

[60] E. Nikkhah, M. Khaiamy, R. Heidary, and A. S. Azar, "The effect of ascorbic acid and $\mathrm{H}_{2} \mathrm{O}_{2}$ treatment on the stability of anthocyanin pigments in berries," Turkish Journal of Biology, vol. 34, no. 1, pp. 47-53, 2010.

[61] E. A. Veal, A. M. Day, and B. A. Morgan, "Hydrogen Peroxide Sensing and Signaling," Molecular Cell, vol. 26, no. 1, pp. 1-14, 2007.

[62] X. Hu, D. L. Bidney, N. Yalpani et al., "Overexpression of a gene encoding hydrogen peroxide-generating oxalate oxidase evokes defense responses in sunflower," Plant Physiology, vol. 133, no. 1, pp. 170-181, 2003.

[63] H. Aoshima, H. Tsunoue, H. Koda, and Y. Kiso, "Aging of whiskey increases 1,1-diphenyl-2-picrylhydrazyl radical scavenging activity," Journal of Agricultural and Food Chemistry, vol. 52, no. 16, pp. 5240-5244, 2004.

[64] D. Del Rio, A. J. Stewart, and N. Pellegrini, "A review of recent studies on malondialdehyde as toxic molecule and biological marker of oxidative stress," Nutrition, Metabolism and Cardiovascular Diseases, vol. 15, no. 4, pp. 316-328, 2005.

[65] K. Jaffel, S. Sai, N. K. Bouraoui et al., "Influence of salt stress on growth, lipid peroxidation and antioxidative enzyme activity in borage (Borago officinalis L.)," Plant Biosystems, vol. 145, no. 2, pp. 362-369, 2011.

[66] H. Esterbauer, F. Muskiet, and D. F. Horrobin, "Cytotoxicity and genotoxicity of lipid-oxidation products," American Journal of Clinical Nutrition, vol. 57, no. 5, pp. 7795-7855, 1993.

[67] D. Weismann, K. Hartvigsen, N. Lauer et al., "Complement factor $\mathrm{H}$ binds malondialdehyde epitopes and protects from oxidative stress," Nature, vol. 478, no. 7367, pp. 76-81, 2011.

[68] A. D. de Azevedo Neto, J. T. Prisco, J. Enéas-Filho, C. E. B. D. Abreu, and E. Gomes-Filho, "Effect of salt stress on antioxidative enzymes and lipid peroxidation in leaves and roots of salttolerant and salt-sensitive maize genotypes," Environmental and Experimental Botany, vol. 56, no. 1, pp. 87-94, 2006. 

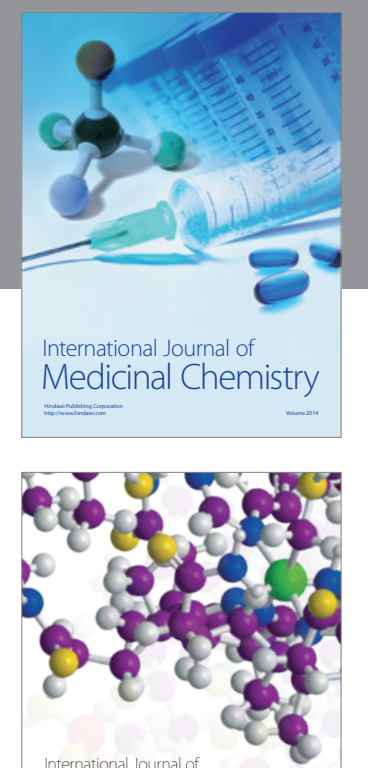

\section{Carbohydrate} Chemistry

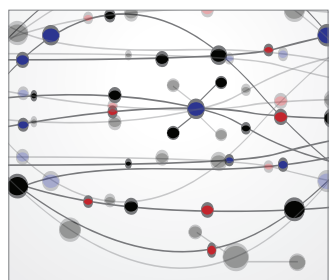

The Scientific World Journal
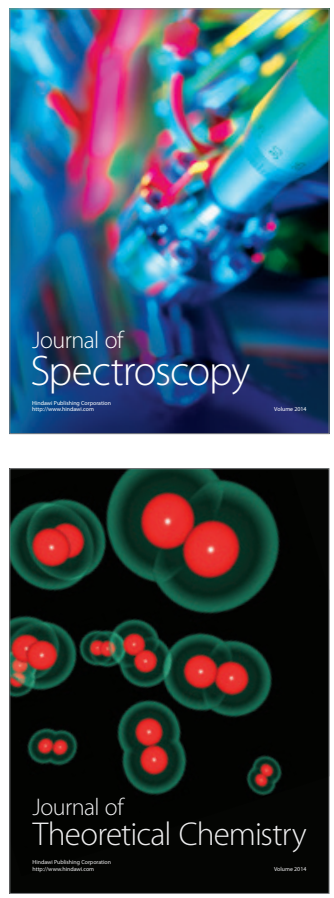
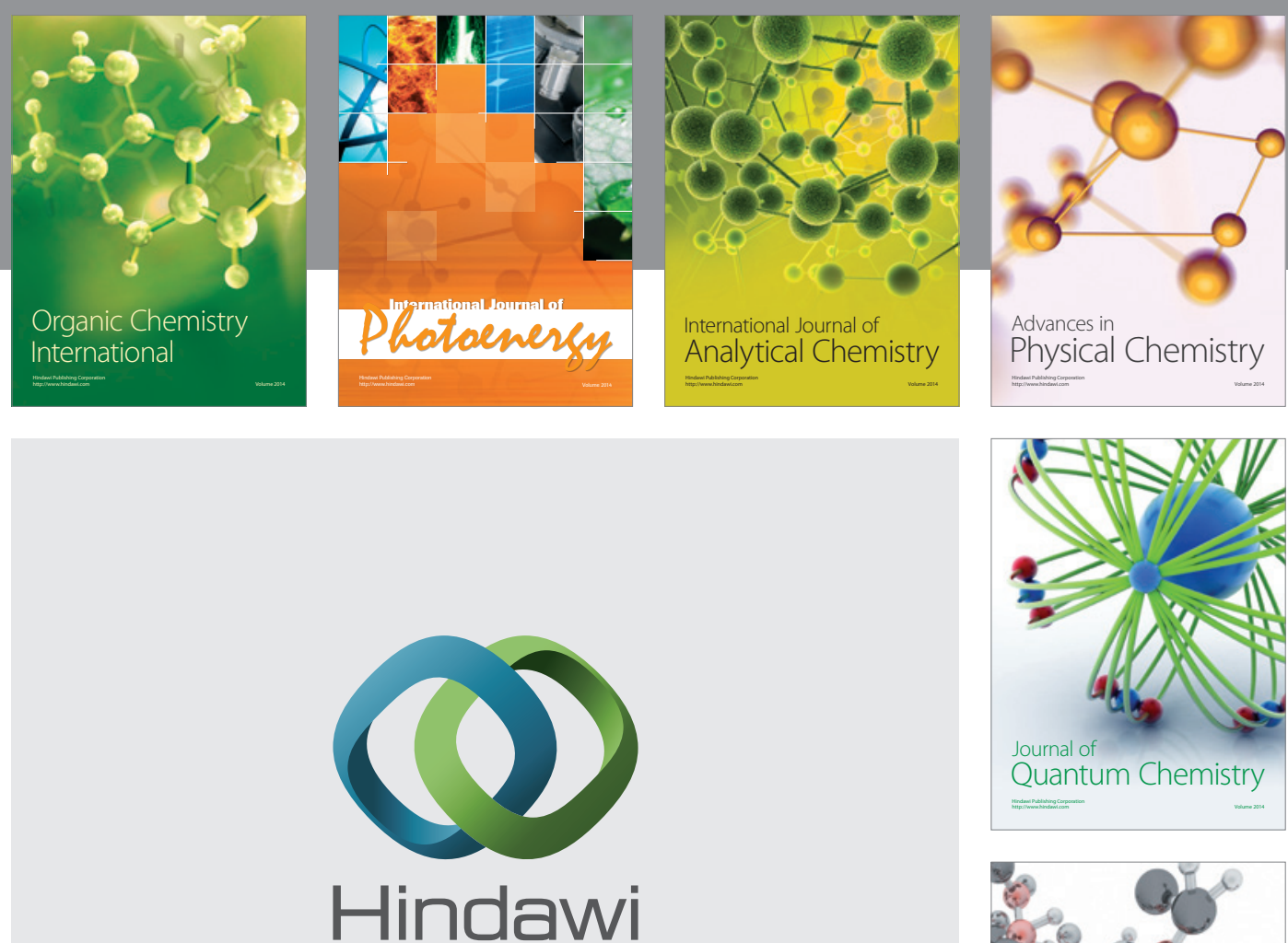

Submit your manuscripts at

http://www.hindawi.com

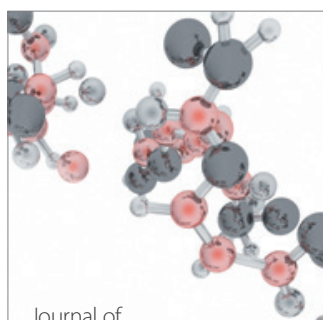

Analytical Methods

in Chemistry

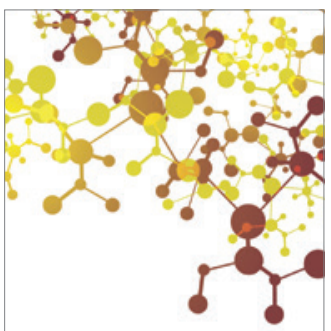

Journal of

Applied Chemistry

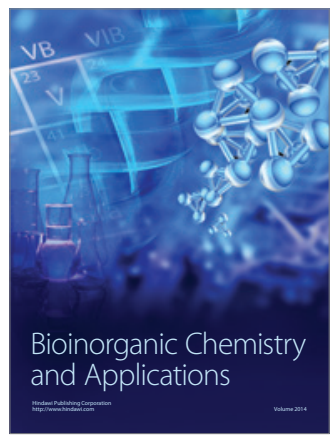

Inorganic Chemistry
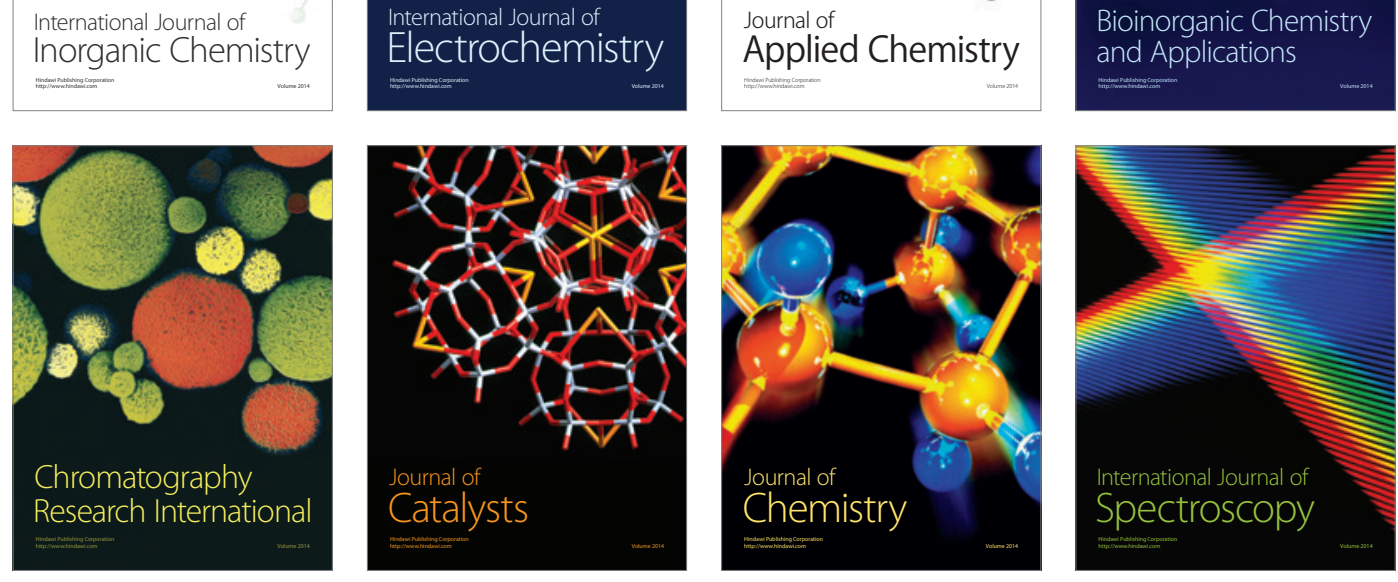